\title{
Bilateral Pathological Damage in Temporal Lobe Epilepsy
}

\author{
Thomas L. Babb
}

\begin{abstract}
Patients with drug-refractory temporal lobe epilepsy can be treated successfully with surgical resection of one temporal lobe, especially when the resection includes the hippocampus. Although intrahippocampal recordings usually localize seizure onsets to one hippocampus, there are bilaterally-independent interictal spikes, occasional contralateral seizure onsets and post-resection seizures that implicate contralateral damage and epileptogenicity. Post-mortem nonquantified studies of both hippocampi in epileptics have revealed incidences of bilateral hippocampal sclerosis, mostly being asymmetric. The present paper reports on two post-mortem cases of bilateral, asymmetric cell loss in patients with physiologically-verified hippocampal epilepsy. In one patient the damage was severe bilaterally, but only slightly greater damage in one hippocampus. In the second patient, damage in one hippocampus was as severe as in the first patient; however the contralateral hippocampus appeared undamaged. However, cell counts revealed losses of over $30 \%$ in three different hippocampal subregions, indicating a mild form of asymmetric bilateral damage in patient two.
\end{abstract}

RÉSUMÉ: Lésions bilatérales dans l'épilepsie temporale. Les patients avec une épilepsie temporale réfractaire à la médication peuvent être traités avec succès par l'ablation chirurgicale d'un lobe temporal, en particulier quand la résection inclut la région de l'hippocampe. Les enregistrements intra-hippocampaux letéralisent habituellement le foyer épileptique dans un hippocampe, mais il y a des cas où l'activité épileptique interictale est bilatérale et indépendante; aussi rencontre-t-on occasionnellement des crises épileptiques à début contralatéral. En plus, la persistance de manifestations critiques après une résection temporale implique souvent un dommage et une épileptogénicité originant des structures contralatérales. Des études autopsiques non quantitatives portant sur les régions hippocampales de patients épileptiques ont démontré plusieurs exemples de sclérose hippocampale bilatérale, cette demière étant le plus souvent asymétrique. Le présent article décrit les études autopsiques de deux patients avec perte cellulaire hippocampale bilatérale et asymétrique et évidence électrophysiologique d'épilepsie hippocampale. Dans un cas, les dommages étaient sévères bilatéralement avec légère prédominance dans l'hippocampe contralatéral au foyer épileptogène. Dans le second cas, les dommages à l'hippocampe du coté du foyer épileptogène étaient sévères, l'hippocampe contralatéral apparaissant intact. Cependant, une analyse quantitative de cette dernière région a démontré une perte cellulaire de plus de $30 \%$ dans les trois différents sous-secteurs étudiés, indiquant un dommage bilatéral asymétrique.

Can. J. Neurol. Sci. 1991; 18: 645-648

There are several facts about temporal lobe epilepsy that suggest bilateral damage to the mesial temporal structures. The extent of such bilateral damage must be considered before unilateral temporal lobectomy, because the opposite temporal lobe may be epileptogenic. In $65 \%$ of unilateral temporal lobectomies the sole pathology is hippocampal sclerosis, virtually restricted to dentate gyrus and Ammon's horn with no significant cell loss to subiculum or parahippocampal gyrus. ${ }^{1}$

The other $35 \%$ are represented by hamartomas, gliomas, and other extrahippocampal temporal cortex pathologies which may co-exist with some minor hippocampal cell loss (dual pathology) but is usually so well circumscribed that such pathologies are probably unilateral. Despite this well-described anatomy of the relative incidence of unilateral temporal lobe damage, it is not possible to determine, after unilateral temporal resection, the incidence of existing contralateral damage and epileptogenicity.

The facts that indicate bilateral damage or epileptogenicity are: 1) With bilateral, homotopic intrahippocampal recordings there are bilaterally-independent interictal spikes whose rates and/or morphology are not related to the seizure onset. ${ }^{2}$ The bilaterality of the SEEG spikes cannot be explained by interhippocampal monosynaptic spread because the hippocampal commissures no longer connect hippocampi in $\operatorname{man}^{3}$ and are only slightly intact in monkeys.4,5 Gradual anticonvulsant drug withdrawal may uncover contralateral hippocampal seizures with a different clinical pattern than the habitual unilateral hippocampal seizures. ${ }^{6}$ After temporal lobectomy, scalp EEG spikes may be found to varying extents contralateral to the lobe removed, regardless of the degree of seizure control. ${ }^{7}$

From the Department of Neurology and The Brain Research Institute, UCLA School of Medicine, University of California, Los Angeles Reprint requests to: Thomas L. Babb, Ph.D., Department of Neurology, University of California, Los Angeles, California, U.S.A. 90024 
After temporal lobectomy, auras may be reported and anticonvulsants required, either of which may indicate a contralateral tendency for epileptogenicity. Hence, it would be a major contribution to our knowledge of hippocampal or temporal lobe epilepsy if we could determine the incidence of truly unilateral versus bilateral pathology. Such information would provide a better understanding of the risks of surgical failure; since we know that the region of maximal hippocampal sclerosis is the site of seizure onset. ${ }^{8}$

Table 1 is a summary of five papers that contained postmortem information on bilateral hippocampal damage in epileptics. In none of the reports was the population limited to temporal lobe epilepsy; all cases had histories of generalized seizures and/or mixed seizure disorders. Furthermore, the pathological diagnosis ranged from visible shrinkage or tangible hardness to microscopic evaluation, but even the excellent quantitative study by Mouritzen-Dam ${ }^{9}$ was limited to only one hippocampus per patient. The bilateral incidence of $88 \%$ was based on visible atrophy, not on cell counts. Hence, there is little information on the relative incidence of bilateral damage in temporal lobe epilepsy.

Perhaps the most widely-quoted study on bilateral hippocampal sclerosis is the paper of Margerison and Corsellis. ${ }^{10}$ Of all the cases studied $(n=55)$ they reported a low incidence of bilateral damage of only $31 \%$ compared to $34 \%$ unilateral and $35 \%$ no damage (see Table 1). Because they depended on microscopic judgment without actual cell counts, it can be safely assumed that they underestimated cell loss because losses of 20$30 \%$ are not detectable under standard microscopic exam. This would suggest that perhaps, with cell counts, there would be a higher incidence of bilateral damage and lower percentage of unilateral or no damage. Nevertheless, when evaluating only those cases with observed hippocampal sclerosis (H.S.), they reported $47 \%$ bilateral damage, of which $75 \%$ were asymmetric

Table 1: Published Reports of Incidence of Bilateral Mesial Temporal Lobe Sclerosis in Epileptic Brains Studied Post-mortem

Bouchet and Cazauvieilh ${ }^{13}$ : Gross Pathology 9/18 $=50 \%$

Bratz ${ }^{14}$ : Microscopic Pathology $1 / 25=4 \%$

Sano and Malamud ${ }^{11}$ : Microscopic Pathology $12 / 18=67 \%$

Margerison and Corsellis ${ }^{10}$ : Microscopic Pathology $17 / 36=47 \%$

Mouritzen-Dam 9 : Microscopic Pathology 15/17 = 88\%

NOTE: None of these studies were limited to temporal lobe epilepsy and used quantitative cell counting.

Table 2: Incidence of Types of Hippocampal Sclerosis (HS) in Postmortem Epileptics Recalculated from Margerison and Corsellis (1966, Figure 7) and from Sano and Malamud (1953, Figure 5I).

Margerison and Corsellis 10

All Cases $(n=55)$ : Bilateral HS $31 \%$, Unilateral HS $34 \%$ No HS

Cases with HS $(n=36)$ : Bilateral HS $47 \%$, Unilateral HS 53\%

Symmetric HS 25\%, Asymmetric HS 75\%

Sano and Malamud ${ }^{\prime \prime}$

All cases $(n=18)$ : Bilateral HS $67 \%$, Unilateral HS $33 \%$

Symmetric HS $8 \%$, Asymmetric HS $92 \%$ (see Table 2). The important point here is that asymmetric damage is apparently the most common pattern when bilateral damage is evident. This is in agreement with Sano and Malamud ${ }^{11}$ who reported bilateral damage (when including gliosis) at $67 \%$, $92 \%$ of the patterns being asymmetric. Hence, from these reports we would anticipate that with proper quantitative studies in temporal lobe epilepsy unilateral H.S. will be extremely rare and bilateral damage will be almost always asymmetric. The following two case reports from the UCLA epilepsy program support this hypothesis.

In 1965 patient T.M. (CNP 17) was evaluated with intrahippocampal recording electrodes and a variety of interictal tests. This was prior to telemetered artifact-free seizure recordings. A left anterior temporal lobectomy was performed and the left hip-

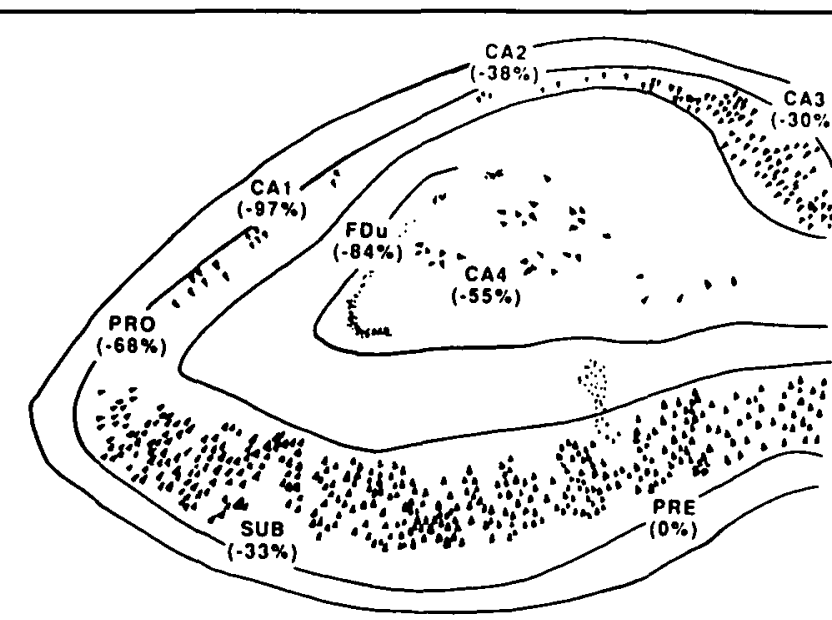

T.M. CNP17 LEFT HIPPOCAMPUS

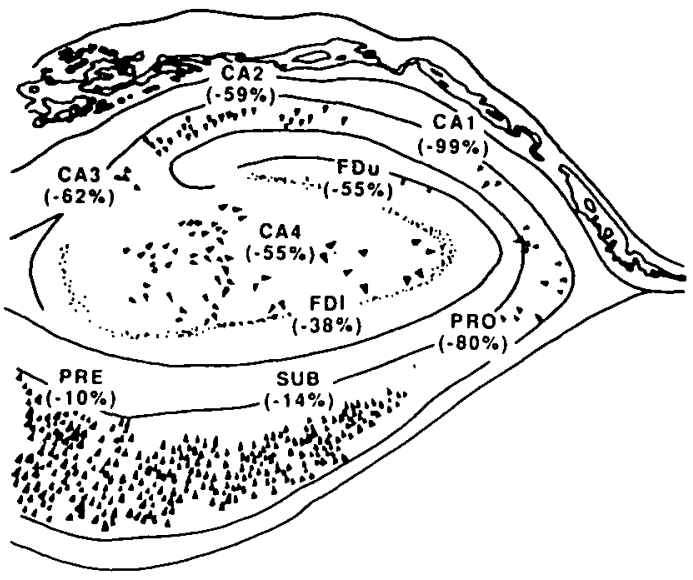

T.M. A8845 RIGHT HIPPOCAMPUS

Figure I-Camera lucida drawings of hippocampal neurons in resected (top) hippocampus and post-mortem (bottom) hippocampus of patient T.M. Percent cell losses from normal control expressed as $\%$ for the following hippocampal regions: FDI: fascia dentata lower blade; FDu: upper blade; CA 4,3,2,1: Cornu Ammonis or Ammon's horn sectors; PRO: prosubiculum; SUB: subiculum; PRE: presubiculum. 
pocampus was highly sclerotic (see Figure 1, top). The patient's habitual seizures were significantly reduced in number; however he continued to have psychomotor seizures and required anticonvulsant medication until his death 12 years later, of unknown causes, in 1977. The autopsy of the right hippocampus (Figure 1 , bottom) showed sclerosis typical of hippocampal epilepsy. In other words, this case probably represents an extreme example of bilateral hippocampal sclerosis and bilateral hippocampal epilepsy with an asymmetric pattern of damage only because the left hippocampus has greater cell loss in several regions of Ammon's horn. For example, the left fascia dentata (FD) had $84 \%$ loss compared to $38 \%$ loss in the right FD.

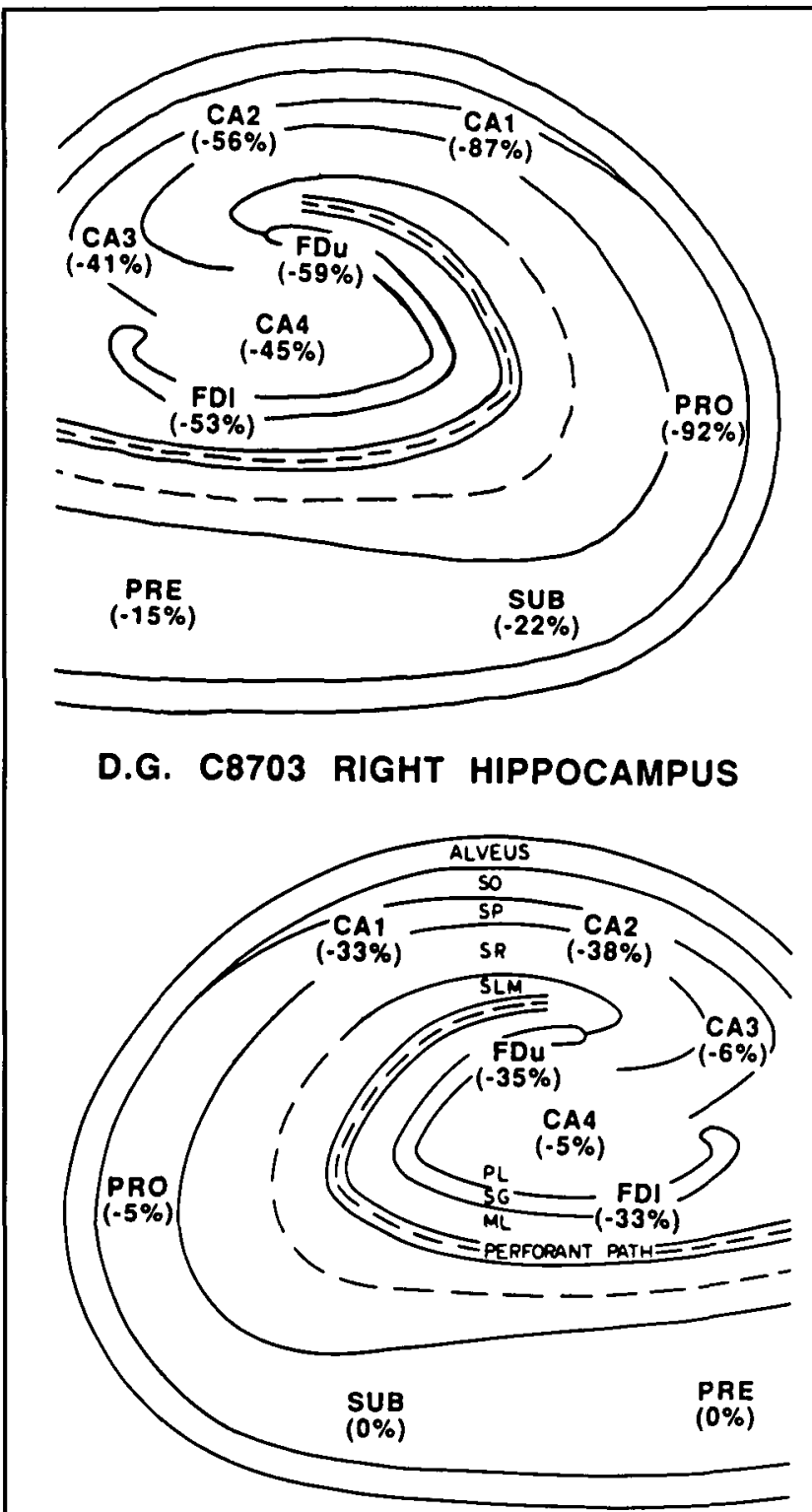

\section{D.G. C8703 LEFT HIPPOCAMPUS}

Figure 2 - Schematic drawings of the right (top) and left (bottom) hippocampi of patient D.G. with percentage cell losses as indicated in Figure 1. Seizures were recorded only from the right hippocampus, but the left hippocampus had some cell loss.
Figure 2 is a plot of cell losses in hippocampus and subiculum for a patient (D.G.) who died at home accidentally before temporal lobectomy could be performed. This patient had a long history of temporal lobe seizures and was diagnosed with bilateral intrahippocampal electrodes as having all habitual temporal lobe seizures arising from the hippocampus during the 28 day seizure monitoring. The SEEG seizure localization and all other evidence led to the recommendation for a right temporal lobectomy. As can be seen in Figure 2, top, the right hippocampus had cell losses typical of those previously reported with hippocampal seizure foci. 8,12

By contrast, the left hippocampus appeared normal to the neuropathologist upon routine microscopic examination. However, cell counts confirmed that in many fields (FD, CA2, CA1) there was over $30 \%$ cell loss (see Figure 2, bottom). This quantitative study demonstrates the opposite of the first case (T.M.) because the hippocampal damage in patient D.G. was overwhelmingly unilateral and associated with the seizure onset. Nevertheless, there were regions of significant contralateral cell loss that indicated a mild form of bilateral asymmetric hippocampal sclerosis. Hence, even in a case where all the diagnostic evidence would suggest a "unilateral" hippocampal sclerosis, there was some bilateral cell loss, which supports the notion that hippocampal epilepsy is a disorder of damage to both hippocampi in varying degrees. It is essential, therefore, to develop as many techniques as possible to establish the integrity of the opposite hippocampus before performing a temporal lobectomy. Such investigations are now becoming routine in the diagnosis of surgically-treatable temporal lobe epilepsy. However, there is a need for more post-mortem quantitative studies such as the two described above. The profound evidence for asymmetric damage together with the lack of evidence for a human hippocampal commissure strongly suggests that bilateral hippocampal sclerosis occurs simultaneously and not by one hippocampus driving the opposite hippocampus to produce contralateral cell loss. That concept of a "mirror focus" of cell loss is not supported by these two case reports, where each had one severely-sclerotic focus but their opposite hippocampi had much different damage profiles.

\section{REFERENCES}

1. Babb TL, Brown WJ. Pathological findings in epilepsy. In: Engel, J, Jr, ed. Surgical Treatment of the Epilepsies. New York: Raven Press 1987; $511-540$

2. Engel J, Jr, Crandall PH, Rausch R. The partial epilepsies. In: Rosenberg RN, Grossman RG, Schochet S. et al., eds. The Clinical Neurosciences. New York: Churchill-Livingstone, 1983; 1349-1380.

3. Wilson $\mathrm{CL}$, Isokwa-Akesson $\mathrm{M}$, Babb $\mathrm{TL}$, et al. A comparative view of local and interhemispheric limbic pathways in humans: an evoked potential analysis. In: Engel J, Jr, ed. Fundamental Mechanisms of Human Brain Function. New York: Raven Press 1987; 27-38.

4. Demeter S, Rosene DL, Van Hoesen GW. Interhemispheric pathways of the hippocampal formation, presubiculum, and entorhinal and posterior parahippocampal cortices in the rhesus monkey: the structure and organization of the hippocampal commissures. J Comp Neurol 1985; 233: 30-47.

5. Amaral DG, Insausti R, Cowan WM. The commissural connections of the monkey hippocampal formation. J Comp Neurol 1984: 224: 307-336.

6. Engel J, Jr, Crandall PH. Falsely localizing ictal onsets with depth EEG telemetry during anticonvulsant withdrawal. Epilepsia 1983; 24: 344-355. 
7. Brazier MAB, Crandall PH. Tests of the predictive value of EEG recording from within the brain in the partial epilepsies. In: Cobb WA, Van Duijn H, eds. Contemporary Clinical Neurophysiology. Amsterdam: Elsevier Scientific Publishing Co. 1978; 83-103.

8. Babb TL, Lieb JP, Brown WJ, et al. Distribution of pyramidal cell density and hyperexcitability in the epileptic human hippocampal formation. Epilepsia 1984b; 25: 721-728.

9. Mouritzen-Dam A. Epilepsy and neuron loss in the hippocampus. Epilepsia 1980; 21: 617-629.

10. Margerison JH, Corsellis JAN. Epilepsy and the temporal lobes. Brain 1966; 89: 499-530.
11. Sano K, Malamud N. Clinical significance of sclerosis of the cornu ammonis. Arch Neurol Psychiatry 1953; 70: 40-53.

12. Babb TL, Brown WJ, Pretorius J, et al. Temporal lobe volumetric cell densities in temporal lobe epilepsy. Epilepsia 1984a; 25: 729-740.

13. Bouchet and Cazauvieilh. De l'épilepsie considérée dans ses rapports avec l'aliénation mentale. Recherche sur la nature et le siège de ces deux maladies; mémoire qui a remporté le prix au concours établi par M. Esquirol. Arch Gen Med 1825; 9: 510542.

14. Bratz E. Ammonshornbefunde der epileptischen. Arch Psychiatr Nervenkr 1899; 31: 820-836. 